\title{
PATOGENISITAS ISOLAT BEAUVERIA BASSIANA DAN METARHIZIUM ANISOPLIAE ASAL TANAH LEBAK DAN PASANG SURUT SUMATERA SELATAN UNTUK AGENS HAYATI SCIRPOPHAGA INCERTULAS
}

\author{
Rosdah Thalib $^{1,3}$, Redi Fernando ${ }^{2}$, Khodijah ${ }^{3,4}$, Dewi Meidalima ${ }^{3,4}$, \& Siti Herlinda ${ }^{1,3^{*}}$ \\ ${ }^{1}$ Jurusan Hama dan Penyakit Tumbuhan, Faperta, Universitas Sriwijaya, Indralaya \\ ${ }^{2}$ Alumni Jurusan Hama dan Penyakit Tumbuhan, Faperta, Universitas Sriwijaya, Indralaya \\ ${ }^{3}$ Pusat Unggulan Riset Pengembangan Lahan Suboptimal (PUR-PLSO), Universitas Sriwijaya, Palembang \\ ${ }^{4}$ Mahasiswa Program Studi Doktor Ilmu Pertanian, Faperta, Universitas Sriwijaya, Palembang \\ *Corresponding author: Telp.+62711580663, Fax.+62711580276Email: sitiherlinda@ unsri.ac.id, sitiherlinda@drn.go.id
}

\begin{abstract}
Pathogeicity of Beauveria bassiana and Metarhizium anisopliae Isolates from Fresh Swamp and Tidal Lowland, South Sumatra for Scirpophaga incertulas Biological Agents. The objectives of the research weret o explore and to determine the pathogenicity of entomopathogenic fungi againts the larvae of Scirpophaga incertulas, and to measure conidial viability and density of the fungi. The method for fungi exploration used larvae of Tenebrio molitor baiting submerged in the soil. The soil was taken from fresh swampand tidal lowland rice in South Sumatra. From the exploration study, we found two species of entomopathogenic fungi: Beauveria bassiana and Metarhizium anisopliae. Mortality of S. incertulas larvae that had been treated topically with fungal conidia $\left(1 \times 10^{6}\right.$ conidia $\left.\mathrm{ml}^{-1}\right)$ varied among the isolates. The highest mortality $(98.33 \%)$ caused by BPlus isolate of B. Bassiana and the lowest by MtmIn isolate of M. anisopliae (57.50\%) and BTmTr isolate of B. bassiana $(57.50 \%)$. The fungal colonies grew fast from the second day up to the fourth day after incubation but the growth became slow after the fifth day. The highest conidial density was resulted by BPcMs of $B$. bassiana isolate $\left(63.33 \times 10^{6} \mathrm{conidia} \mathrm{ml}^{-1}\right)$ but this density was not significantly different from that of the BPlus of $B$. bassiana isolate $\left(63.11 \times 10^{6}\right.$ conidia $\left.\mathrm{ml}^{1}\right)$. The lowest conidial density found in BTmTr of B. bassiana isolate $\left(20.97 \times 10^{6}\right.$ conidia $\left.\mathrm{ml}^{-1}\right)$. The isolate $B$. bassiana was more effective than M. anisopliae againt the larvae of S.incertulas.
\end{abstract}

Key words: Beauveria bassiana, Metarhizium anisopliae, fresh swamp, tidal lowland

\begin{abstract}
ABSTRAK
Patogenisitas Isolat Beauveria bassiana dan Metarhizium anisopliae asal Tanah Lebak dan Pasang Surut Sumatera Selatan untuk Agens Hayati Scirpophaga incertulas. Penelitian ini bertujuan untuk mengeksplorasi dan menentukan patogenisitas isolat jamur entomopatogen terhadap larva Scirpophaga incertulas dan menghitung viabilitas dan kerapatan jamur tersebut. Metode ekplorasi jamur menggunakan metode umpan serangga dengan larva Tenebrio molitor, larva tersebut dibenamkan ke dalam tanah untuk memerangkap konidia jamur yang ada di dalam tanah. Tanah tersebut diambil dari sentra padi lahan rawa lebak dan pasang surut. Dari eksplorasi tersebut ditemukan dua spesies jamur entomopatogen, yaitu Beauveria bassiana and Metarhizium anisopliae. Hasil penelitian menunjukkan bahwa mortalitas larva $S$. incertulas yang diaplikasikan

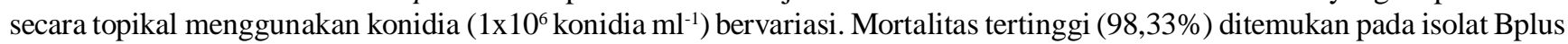
B. bassiana dan terendah ditemukan pada $\mathrm{MTmIn}(57,50 \%)$ isolat M. anisopliae dan $\mathrm{B} \operatorname{Tm} \operatorname{Tr}(57,50 \%)$ isolat B. bassiana. Koloni jamur tumbuh lebih cepat mulai hari kedua hingga keempat setelah inkubasi tetapi pertumbuhan semakin lambat setelah hari kelima. Kerapatan konidia tertinggi terjadi pada isolat $B$. Bassiana $\mathrm{BPcMs}\left(63,33 \times 10^{6} \mathrm{konidia} \mathrm{ml}^{-1}\right)$, namun kerapatan

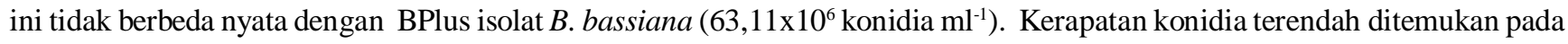

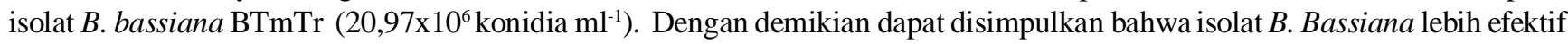
diandingkan M. anisopliae dalam hal membunuh larva S. incertulas.
\end{abstract}

Kata kunci: Beauveria bassiana, Metarhizium anisopliae, rawa lebak, pasang surut

\section{PENDAHULUAN}

Penggerek batang padi kuning, Scirpophaga incertulas (Lepidoptera: Pyralidae) merupakan serangga hama penting yang menyerang tanaman padi di tanah lebak dan pasang surut Sumatera Selatan (Khodijah et al., 2012). Hama ini dapat menyerang fase vegetatif (sundep) maupun generatif (beluk) (Wilyus et 
al., 2012). Gejala sundep menyebabkan pucuk padi mati, kerdil dan mati, sedangkan beluk menyebabkan malai mati sehingga bulirnya hampa dan malai putih keabu-abuan tetap tegak (Usyati et al., 2009).

Penggerek batang padi meletakkan telurnya di permukaan daun secara berkelompok. Larva instar pertama biasanya masih bergerombol di permukaan daun atau batang. Fase telur dan larva muda ini merupakan fase yang paling mudah dalam pengendaliannya secara kontak karena larva belum menggerek dan masuk ke dalam batang. Pengendalian penggerek batang secara kontak dapat menggunakan jamur entomopatogen yang bekerjanya secara kontak karena relatif lebih aman dibandingkan pengendalian menggunakan insektisida sintetik. Jamur entomopatogen telah dilaporkan dapat menggendalikan serangga hama dari ordo Lepidoptera lainnya (Herlinda et al., 2005a, 2005b). Jamur, Beauveria bassiana dan Metarhizium anisopliae telah ditemukan pada tanah lebak Sumatera Selatan (Herlinda et al., 2005c) dan terbukti dapat membunuh kutu daun (Aphis gossypii) (Herlinda, 2010; Herlinda et al., 2010), ulat daun kubis Plutella xylostella (Herlinda et al., 2005a,b; Nunilahwati et al., 2012), kepik kubis (Herlinda et al., 2006a), wereng coklat (Herlinda et al., 2008a), dan walang sangit (Leptocorisa oratorius) (Herlinda et al., 2008b). Jamur entomopatogen pada penelitian ini telah dieksplorasi baik dari tanah lebak maupun pasang surut. Jamur entomopatogen tersebut belum diketahui potensinya dalam membunuh larva penggerek batang padi. Penelitian ini bertujuan untuk mengeksplorasi dan menentukan patogenisitas isolat jamur entomopatogen terhadap larva S.incertulas dan menghitung viabilitas dan kerapatan jamur tersebut.

\section{METODE PENELITIAN}

Penelitian dilaksanakan di Laboratorium Entomologi dan Rumah Kaca Jurusan Hama dan Penyakit Tumbuhan Fakultas Pertanian Universitas Sriwijaya di Indralaya. Penelitian ini dilaksanakan pada bulan Februari hingga Agustus 2012, pada suhu dan kelembaban nisbi ruangan rata-rata $29,20{ }^{\circ} \mathrm{C}$ dan $92,33 \%$.

Pemeliharaan Serangga Uji. Imago $S$. incertulas dikumpulkan dari pertanaman padi di rawa lebak dan pasang surut Sumatra Selatan, kemudian dibawa dan dipelihara dalam kurungan kasa $(150 \mathrm{~cm}$ x $150 \mathrm{~cm}$ x $100 \mathrm{~cm}$ ) yang didalamnya telah dimasukkan tanaman padi berumur 8 minggu untuk pakan dan tempat perkembangbiakan. Selanjutnya setelah penggerek batang padi menjadi imago dipisahkan ke tanaman baru, sehingga menghasilkan telur berupa keturunan F2 dan seterusnya dan larva yang digunakan untuk aplikasi berupa larva instar pertama.

Eksplorasi, Isolasi, dan Identifikasi Jamur Entomopatogen. Metode eksplorasi yang digunakan pada penelitian ini ialah metode umpan serangga dengan memodifikasi metode Hasyim \& Azwana (2003) dan Herlinda et al.(2010). Serangga umpan yang digunakan adalah ulat hongkong (Tenebrio molitor L.) instar ketiga yang baru berganti kulit. Tanah yang merupakan tempat untuk memerangkap jamur entomopatogen tersebut diambil secara purposive sampling dari tanah sentra sawah lebak dan pasang surut di Sumatera Selatan. Tanah diambil dengan cara menggali pada kedalaman $5-15 \mathrm{~cm}$. Tanah dibawa ke laboratorium sebanyak $1 \mathrm{~kg}$, lalu dimasukkan ke nampan plastik (13 x $\left.13 \times 10 \mathrm{~cm}^{3}\right)$. Ulat hongkong instar ketiga yang baru ganti kulit dibenamkan sedalam $2 \mathrm{~cm}$ di dalam tanah tersebut sebanyak 20 ekor per nampan. Kegiatan ini diulang 10 kali. Lalu, nampan ditutupi dengan potongan kain puring hitam yang telah dilembabkan dengan air steril. Tiga hari kemudian ulat diperiksa dan yang terinfeksi jamur diisolasi di laboratorium.

Isolasi dilakukan dengan cara larva yang telah mati terinfeksi jamur yang dicirikan dengan tubuh kering seperti mumi dan tumbuhnya hifa di permukaan tubuhnya selanjutnya dicelupkan ke dalam alkohol $70 \%$ selama 2 menit dan dicelupkan pada air steril selama 1 menit. Larva yang telah steril ditumbuhkan di dalam media GYA (Glucose Yeast Agar) yang metode pembuatannya mengikuti metode Herlinda et al. (2006b), lalu diinkubasikan pada suhu kamar selama 7 hari. Isolat yang sudah murni selanjutnya diidentifikasi mengikuti metode Bidochka et al. (2000).

Pengamatan Patogenisitas Isolat Jamur. Masingmasing isolat baik hasil eksplorasi maupun koleksi laboratorium (untuk pembanding) (Tabel 1) diuji patogenisitasnya terhadap larva $S$. incertulas instar pertama. Suspensi konidia jamur yang diteteskan secara topikal pada 20 ekor larva instar pertama sebanyak 10

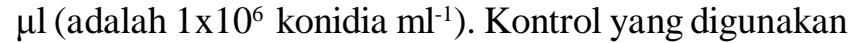
pada penelitian ini adalah air steril yang diteteskan pada larva sebanyak $10 \mu$ l. Larva yang telah diteteskan tadi dipelihara di dalam plastik silinder (diameter $9 \mathrm{~cm}$ dan tinggi $30 \mathrm{~cm}$ ) yang ditutup kain kasa yang di dalamnya berisi 20 batang tanaman padi umur 30 hari untuk pakan dan habitat larva. Setelah 10 hari, batang tanaman padi tersebut dibelah untuk menentukan jumlah larva yang mati dan yang masih hidup. Larva yang mati disterilkan 
Tabel 1. Isolat B. bassiana dan M. anisopliae hasil eksplorasi dan koleksi laboratorium yang digunakan pada penelitian

\begin{tabular}{llll}
\hline Jenis jamur & Serangga sumber infeksi & Asal lokasi & Kode isolat \\
\hline Hasil eksplorasi & & & \\
\hline B. bassiana & Tenebrio molitor & Pemulutan & BTmPe \\
B. bassiana & Tenebrio molitor & Maryana & BTmMa \\
B. bassiana & Tenebrio molitor & Mulya Sari & BTmTs \\
B. bassiana & Tenebrio molitor & Telang Karya & BTmTk \\
B. bassiana & Tenebrio molitor & Telang Rejo & BTmTr \\
B. bassiana & Tenebrio molitor & Saleh Mulya & BTmSm \\
B. bassiana & Tenebrio molitor & Makarti Jaya & BTmMj \\
B. bassiana & Tenebrio molitor & Srikaton & BTmSr \\
B. bassiana & Tenebrio molitor & Rambutan & BTmRa \\
M. anisopliae & Tenebrio molitor & Indralaya & MTmIn \\
\hline Koleksi laboratorium & & & \\
\hline M. anisopliae & Aphis gossypii & Indralaya & MAgIn \\
M. anisopliae & Tenebrio molitor & Muarasiban & MTmMs \\
M. anisopliae & Tenebrio molitor & Jarai & MTmJr \\
M.anisopliae & Aphis gossypii & Pagardin & MAgPd \\
B. bassiana & Pseudoplusia chalcites & Muarasiban & BPcMs \\
B. bassiana & Leptocorisa acuta & Pantura & BWsPantura \\
B. bassiana & Pseudoplusia chalcites & Pagardin & BPcPd \\
B. bassiana & Chrysodeixis chalcites & Pagaralam & BPlus \\
B. bassiana & Lipaphis erysimi & Pagardin & BLePd \\
B. bassiana & Tenebrio molitor & Gandus & BTmGa \\
\hline & & &
\end{tabular}

menggunakan alkohol 70\%, selanjutnya ditumbuhkan di medium GYA untuk mendeteksi infeksi jamur. Percobaan ini diulang sebanyak enam kali dengan menggunakan Rancangan Acak lengkap (RAL). Perbedaan data mortalitas larva antar isolat jamur dianalisis secara statistik menggunakan Analysis of Variance (Anova) yang dilanjutkan dengan uji Beda Nyata Terkecil (BNT) pada taraf nyata 5\%, dengan program SAS-STAT pada SAS 6.12.

\section{Pengamatan Pertumbuhan Koloni Jamur,} Kerapatan dan Viabilitas Konidia. Pertumbuhan koloni jamur diamati pada medium GYA. Satu bor gabus koloni jamur masing-masing isolat diinokulasikan ke dalam cawan petri (diameter $90 \mathrm{~mm}$ ) yang berisi medium GYA dan diinkubasikan selama 7 hari pada suhu ruangan tetapi setiap hari dihitung jumlah koloni yang terbentuk dengan menggunakan colony counter. Data tentang jumlah koloni jamur yang terbentuk dianalisis secara deskriptif dan data ditampilkan dalam bentuk tabel.

Pengamatan kerapatan dan viabilitas konidia jamur mengikuti metode Herlinda et al. (2010). Isolat jamur ditumbuhkan pada medium GYA yang diperkaya dengan tepung jangkrik, lalu diinkubasikan selama 7 hari pada suhu ruangan. Konidia jamur diambil dari biakan tadi sebanyak $1 \mathrm{~g}$ dan ditambahkan pada $9 \mathrm{ml}$ air steril untuk dijadikan suspensi jamur. Kemudian kerapatan konidianya dihitung menggunakan haemocytometer di bawah mikroskop.

Viabilitas konidia diamati dengan cara membuat suspensi seperti pada pengamatan kerapatan konidia sebanyak $100 \mathrm{ml}$. Lalu suspensi tersebut diinkubasikan selama 24, 48, dan 72 jam pada suhu ruangan. Setiap 24 jam diambil $1 \mathrm{ml}$ suspensi untuk diamati jumlah konidia yang berkecambah. Persentase perkecambahan ditentukan dengan cara menghitung jumlah konidia yang berkecambah dibandingkan dengan total konidia dikali dengan persentase perkecambahan, seperti metode penghitungan Herlinda et al. (2010). Percobaan ini diulang sebanyak enam kali dengan menggunakan Rancangan Acak lengkap (RAL). Perbedaan data kerapatan dan viabilitas konidia antar isolat jamur dianalisis secara statistik menggunakan Anova yang dilanjutkan dengan uji beda nyata terkecil (BNT) pada 
taraf nyata 5\%, dengan bantuan program SAS-STAT pada SAS 6.12.

\section{HASIL DAN PEMBAHASAN}

Patogenisitas Isolat Jamur. Spesies jamur entomopatogen yang ditemukan dari tanah lebak dan pasang surut Sumatera Selatan adalah B. bassiana and M. anisopliae. Hasil aplikasi secara topikal pada larva S. incertulas instar pertama menunjukkan larva mati dengan gejala kering seperti mumi. Bagian permukaan luar tubuh larva ditumbuhi miselia berwarna putih untuk $B$. bassiana dan putih kehijauan untuk $M$. anisopliae (Gambar 1A-B). Koloni B. bassiana berwarna putih, sedangkan koloni $M$. anisopliae berwarna putih kehijauan (Gambar 1C-D). Larva yang terinfeksi jamur entomopatogen ini tidak mengeluarkan bau dan tubuh mengkerut dan kering. Gejala yang sama juga telah dilaporkan oleh Herlinda et al. (2006b) pada larva $P$. xylostella yang terinfeksi $B$. bassiana dan Herlinda et al. (2008b) pada nimfa walang sangit yang terinfeksi M. anisopliae.
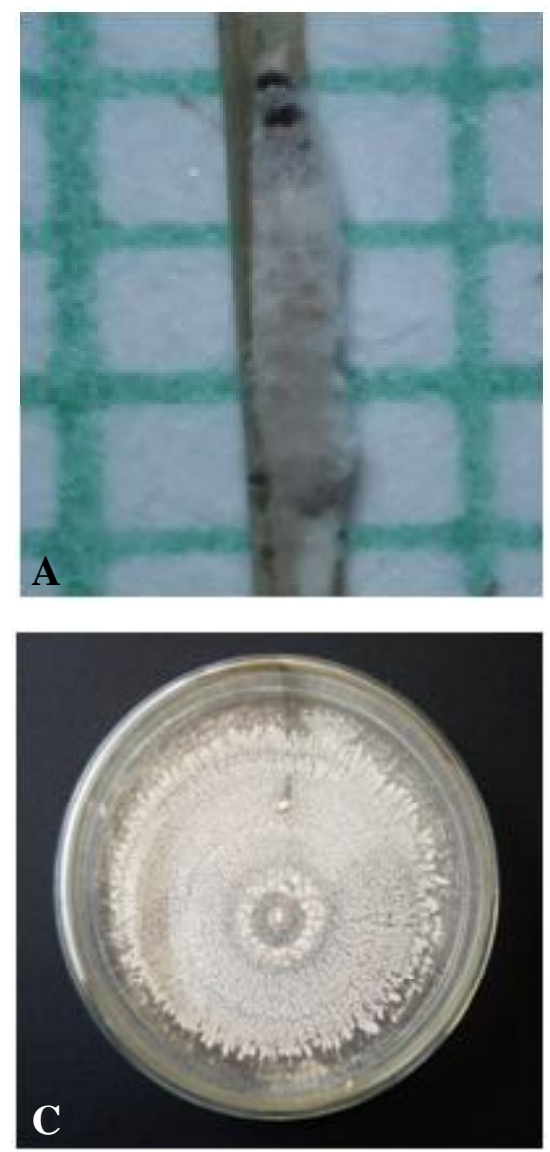

Tanaman padi yang digunakan untuk pakan larva yang diinokulasikan konidia jamur dan kontrol (air steril) pada penelitian ini menunjukkan gejala serangan yang berbeda (Gambar 2). Tanaman padi pada perlakuan dengan larva $S$. incertulas yang telah diinokulasikan konidia $B$. bassiana atau $M$. anisopliae memperlihatkan gejala masih tetap segar dan daun tetap berwarna hijau, sedangkan pada tanaman padi yang diinfestasikan dengan larva yang hanya diteteskan air steril (kontrol) menunjukkan gejala sundep. Gejala sundep pada penelitian ini dicirikan pucuk mati, daun menguning, kering dan pertumbuhan tanaman terhenti. Tanaman padi pada perlakuan yang larvanya diaplikasikan konidia jamur ini terlihat masih hijau dan segar diakibatkan larva umumnya mati sebelum lebih jauh menggerek dan memakan jaringan batang. Menurut Prayogo et al. (2005) serangga yang terinfeksi jamur entomopatogen umumnya menunjukkan gejala penurunan selera makan, aktivitas pergerakan menjadi lambat, lemas, perilaku abnormal, dan diakhiri dengan kematian. Fenomena pada peneliti ini menunjukkan bahwa adanya inokulasi konidia jamur pada instar
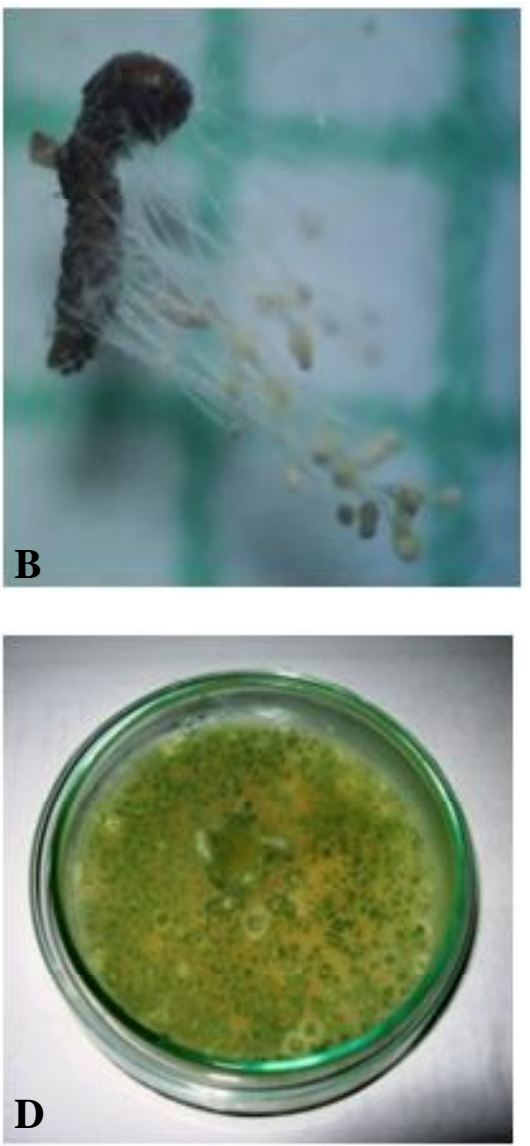

Gambar 1. Gejala larva S. incertulas yang terinfeksi B. bassiana (A), terinfeksi M. anisopliae (B) dan warna serta bentuk koloni B. bassiana (C) dan M. anisopliae (D). 
pertama S. incertulas yang biasanya di lapangan masih belum menggerek batang cukup efektif mencegah serangan larva penggerek pada tanaman padi.
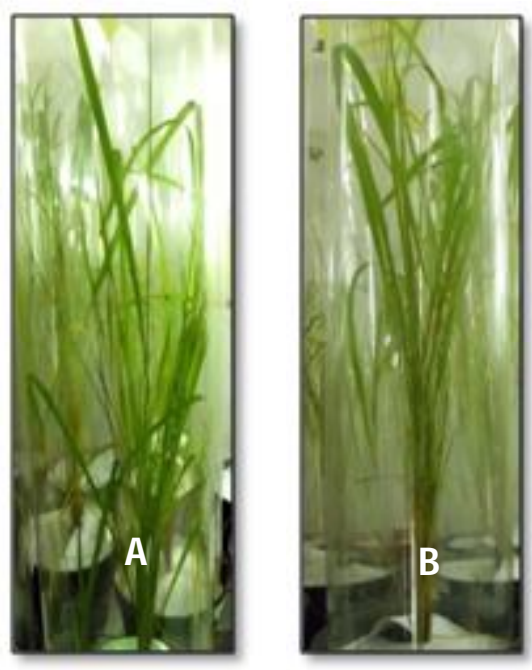

Hari ke-2

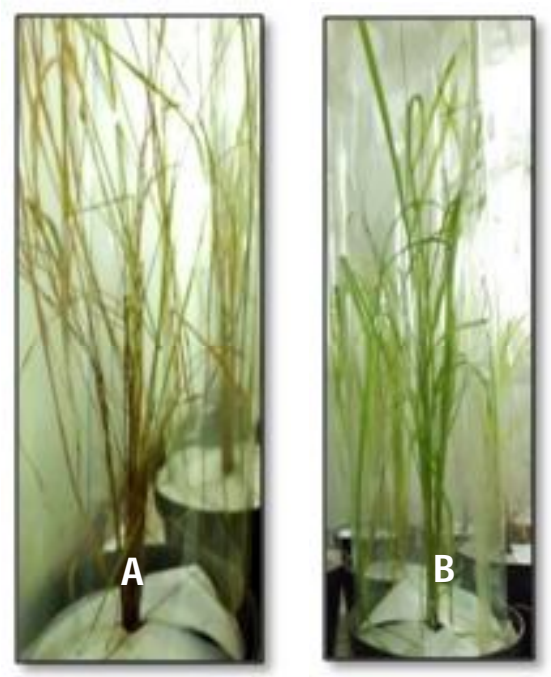

Hari ke-5
Pembuktian bahwa adanya kematian larva $S$. incertulas akibat inokulasi konidia jamur dapat ditunjukkan dengan tingginya data mortalitas larva

Gambar 2. Gejala serangan larva S. incertulas pada tanaman padi yang tidak diaplikasikan (A) dan yang diaplikasikan konidia $B$. bassiana (B) pada hari ke-2, 5, dan 8 setelah diinfestasikan larva.

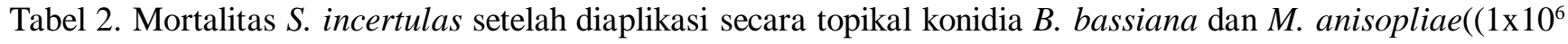
konidia $\mathrm{mL}^{-1}$ )

\begin{tabular}{lc}
\hline \multicolumn{1}{c}{ Kode Isolat } & Rata-rata mortalitas $(\%)$ \\
\hline BPcMs & $91,67 \mathrm{~h}$ \\
BWsPantura & $88,33 \mathrm{~h}$ \\
BPcPd & $87,50 \mathrm{gh}$ \\
BPlus & $98,33 \mathrm{i}$ \\
BLePd & $60,00 \mathrm{~b}$ \\
BTmGa & $65,83 \mathrm{bcd}$ \\
BTmPe & $78,33 \mathrm{cde}$ \\
BTmMa & $69,17 \mathrm{bcd}$ \\
BTmTs & $64,17 \mathrm{bc}$ \\
BTmTk & $85,00 \mathrm{fgh}$ \\
BTmTr & $57,50 \mathrm{~b}$ \\
BTmSm & $71,67 \mathrm{bcde}$ \\
BTmMj & $66,67 \mathrm{bcd}$ \\
BTmSr & $77,50 \mathrm{cde}$ \\
BTmRa & $80,00 \mathrm{defg}$ \\
MTmMs & $70,00 \mathrm{bcde}$ \\
MTmJr & $66,67 \mathrm{bcd}$ \\
MTmIn & $57,50 \mathrm{~b}$ \\
MAgIn & $84,17 \mathrm{efgh}$ \\
MAgPd & $65,00 \mathrm{bc}$ \\
Kontrol (air steril) & $1,67 \mathrm{a}$ \\
\hline BNT & $9,5405)$ \\
\hline Ang & 9,54 \\
\hline
\end{tabular}

Angka yang diikuti oleh huruf yang sama menunjukkan tidak berbeda nyata berdasar uji $\mathrm{BNT}_{0,05}$. 
pelakuan bila dibandingkan dengan kontrol (Tabel 2). Mortalitas larva S. incertulas tertinggi $(98,33 \%)$ ditemukan pada isolat Bplus $B$. Bassiana dan terendah ditemukan pada MTmIn (57,50\%) isolat M. anisopliae yang tidak berbeda nyata dengan $\mathrm{BTmTr}(57.50 \%)$ isolat B. bassiana. Dua spesies jamur yang dicobakan pada penelitian ini menujukkan kecenderungan $B$. bassiana lebih tinggi menyebabkan mortalitas larva $S$. incertulas dibandingkan $M$. anisopliae. Berbagai laporan dari peneliti sebelumnya menunjukkan bahwa memang $B$. bassiana cenderung lebih patogenik dibandingkan $M$. anisopliae dalam membunuh larva dari ordo Lepidoptera maupun ordo lainnya (Bustillo et al., 1999; Lui \& Bauer, 2006; Herlinda et al., 2010). Pengaruh inokulasi konidia jamur untuk penggerek batang ini efektif bila dilakukan pada larva instar pertama atau fase telur karena jamur entomopatogen membunuh dengan cara kontak, sedangkan aplikasi yang ditujukan ke larva instar lebih tua kurang efektif karena larva sudah mulai menggerek dan masuk dalam batang padi.

Pertumbuhan Koloni Jamur, Kerapatan, dan Viabilitas Konidia Jamur. Keunggulan lainnya dari B. bassiana selain lebih patogenik membunuh larva $S$. incertulas yang telah diuraikan di atas, juga memiliki laju pertumbuhan koloni, kerapatan, dan viabilitas konidianya cenderung lebih tinggi dibandingkan $M$. anisopliae. Pertumbuhan koloni isolat-isolat $B$. bassiana dan $M$. anisopliae menunjukkan laju pertumbuhan lebih cepat mulai hari kedua hingga keempat, namun pada hari kelima dan keenam pertambahan jumlah koloni semakin lambat (Tabel 3). Jumlah koloni terbanyak pada pengamatan hari keenam ditemukan pada isolat $B$. bassiana (BTmTk), yaitu ratarata 554 koloni, sedangkan untuk isolat $M$. anisopliae terbanyak ditemukan hanya 186,67 koloni pada isolat MAgIn.

Kerapatan konidia jamur paling tinggi ditemukan pada isolat $B$. bassiana, yaitu isolat BPcMs $(63,33 \mathrm{x}$ $10^{6}$ konidiamL $^{-1}$ ) yang tidak berbeda nyata dengan isolat BPlus $\left(63,11 \times 10^{6}\right.$ konidia $\left.\mathrm{mL}^{-1}\right)$, sedangkan kerapatan konidia $M$. anisopliae tertinggi hanya mencapai 38,33 x $10^{6}$ konidia $\mathrm{mL}^{-1}$ pada isolat MAgIn (Tabel 4). Viabilitas konidia jamur semakin meningkat dengan semakin lamanya masa inkubasi suspensi jamurnya (Tabel 4). Viabilitas konidia pada umur suspensi 72 jam tertinggi ditemukan pada isolat $B$. bassiana berkode BPlus sebesar $81,33 \%$, sedangkan viabilitas terendah pada isolat M. anisopliae berkode MtmIn sebesar 34\%. Kerapatan dan viabilitas konidia erat kaitannya dalam

Tabel 3. Jumlah koloni B. bassiana dan M.anisopliae sejak hari ke-2 hingga ke-6

\begin{tabular}{|c|c|c|c|c|c|c|c|c|c|c|}
\hline \multirow{3}{*}{$\begin{array}{l}\text { Kode isolat } \\
\text { BPcMs }\end{array}$} & \multicolumn{10}{|c|}{ Rata-rata jumlah koloni (koloni) hari ke- } \\
\hline & \multicolumn{2}{|l|}{2} & \multicolumn{2}{|c|}{3} & \multicolumn{2}{|c|}{4} & \multicolumn{2}{|l|}{5} & \multicolumn{2}{|c|}{6} \\
\hline & 6,67 & abcd & 22,67 & efg & 53,67 & fgh & 100,00 & def & 103,00 & cdef \\
\hline BWsPantura & 8,33 & cde & 21,33 & def & 44,00 & ef & 102,67 & defg & 105,33 & defg \\
\hline $\mathrm{BPcPd}$ & 5,00 & $a b c$ & 13,33 & bcd & 37,33 & cdef & 91,00 & cde & 93,00 & cde \\
\hline BPlus & 14,00 & $\mathrm{fg}$ & 29,33 & gh & 70,00 & ghi & 146,33 & hi & 148,33 & hi \\
\hline BLePd & 3,33 & $\mathrm{ab}$ & 10,33 & $a b c$ & 25,67 & abcd & 67,67 & bcd & 72,00 & bcd \\
\hline BTmGa & 10,67 & def & 22,00 & efg & 51,33 & fg & 119,67 & efgh & 120,67 & efgh \\
\hline BTmPe & 28,67 & $\mathrm{i}$ & 76,00 & $\mathrm{k}$ & 150,00 & 1 & 292,33 & $\mathrm{k}$ & 301,00 & $\mathrm{k}$ \\
\hline BTmMa & 16,33 & $\mathrm{gh}$ & 40,67 & $\mathrm{ij}$ & 78,00 & $\mathrm{ij}$ & 159,33 & hi & 148,67 & hi \\
\hline BTmTs & 20,33 & $\mathrm{~h}$ & 49,00 & $\mathrm{j}$ & 101,33 & $\mathrm{k}$ & 222,67 & $\mathrm{j}$ & 229,33 & $\mathrm{j}$ \\
\hline BTmTk & 59,33 & $\mathrm{j}$ & 119,33 & 1 & 267,67 & $\mathrm{~m}$ & 550,67 & 1 & 554,00 & 1 \\
\hline $\mathrm{BTmTr}$ & 2,33 & $\mathrm{a}$ & 5,67 & $a b$ & 9,33 & $\mathrm{a}$ & 19,00 & $\mathrm{a}$ & 25,33 & $\mathrm{a}$ \\
\hline BTmSm & 3,67 & $a b c$ & 8,33 & $\mathrm{ab}$ & 21,67 & $a b c$ & 58,67 & $\mathrm{abc}$ & 60,33 & $a b c$ \\
\hline $\mathrm{BTmMj}$ & 2,67 & $a b$ & 8,67 & $a b$ & 26,00 & abcde & 62,33 & bcd & 63,33 & abcd \\
\hline $\mathrm{BTmSr}$ & 2,33 & $\mathrm{a}$ & 4,33 & $\mathrm{a}$ & 15,00 & $a b$ & 39,00 & $a b$ & 42,00 & $a b$ \\
\hline BTmRa & 12,67 & efg & 27,33 & fgh & 69,00 & ghi & 140,67 & fghi & 140,67 & fgh \\
\hline MTmMs & 6,33 & abcd & 17,33 & cde & 43,67 & def & 96,67 & cde & 99,67 & cdef \\
\hline MTmJr & 14,33 & fg & 33,00 & hi & 70,33 & hi & 143,33 & ghi & 147,00 & ghi \\
\hline MTmIn & 10,67 & def & 23,33 & efg & 59,33 & fghi & 121,00 & efgh & 127,33 & efgh \\
\hline MAgIn & 17,33 & $\mathrm{gh}$ & 43,67 & $\mathrm{j}$ & 92,00 & $\mathrm{jk}$ & 180,00 & $\mathrm{i}$ & 186,67 & $\mathrm{ij}$ \\
\hline MAgPd & 7,33 & bcd & 20,33 & def & 42,33 & def & 93,33 & cde & 105,67 & defgh \\
\hline $\mathrm{BNT}_{(0,05)}$ & 4,91 & & 8,45 & & 18,97 & & 41,83 & & 43,10 & \\
\hline
\end{tabular}

Angka dalam lajur yang diikuti oleh huruf yang sama menunjukkan tidak berbeda nyata berdasar uji $\mathrm{BNT}_{0.05}$. 
Tabel 4. Kerapatan dan viabilitas konidia isolat B. bassiana dan M. anisopliae

\begin{tabular}{|c|c|c|c|c|}
\hline \multirow{2}{*}{ Kode isolat } & \multirow{2}{*}{$\begin{array}{l}\text { Kerapatan konidia } \\
\left(\times 10^{6} \text { konidia } \mathrm{mL}^{-1}\right)\end{array}$} & \multicolumn{3}{|c|}{ Viabilitas konidia (\%) pada umur suspensi jamur ke- } \\
\hline & & 24 jam & $48 \mathrm{jam}$ & 72 jam \\
\hline BPcMs & $63,33 \mathrm{k}$ & $42,33 \mathrm{j}$ & $58,67 \mathrm{k}$ & $66,00 \mathrm{~m}$ \\
\hline BWsPantura & $60,39 \mathrm{j}$ & $40,33 \mathrm{i}$ & $54,33 \mathrm{j}$ & $64,00 \mathrm{kl}$ \\
\hline $\mathrm{BPcPd}$ & $59,28 \mathrm{j}$ & $40,67 \mathrm{ij}$ & $57,00 \mathrm{k}$ & $64,67 \mathrm{~lm}$ \\
\hline BPlus & $63,11 \mathrm{k}$ & $47,00 \mathrm{k}$ & 68,001 & $81,33 \mathrm{n}$ \\
\hline BLePd & $25,07 \mathrm{bc}$ & $28,67 \mathrm{abc}$ & $33,67 \mathrm{~b}$ & $36,33 \mathrm{~b}$ \\
\hline BTmGa & $29,63 \mathrm{~d}$ & $27,00 \mathrm{a}$ & $35,00 \mathrm{bc}$ & $41,67 \mathrm{~d}$ \\
\hline BTmPe & $39,97 \mathrm{~g}$ & 32,33 ef & $44,00 \mathrm{~h}$ & $53,00 \mathrm{~h}$ \\
\hline BTmMa & $37,08 \mathrm{f}$ & $28,33 \mathrm{ab}$ & $37,00 \mathrm{~cd}$ & $46,33 \mathrm{e}$ \\
\hline BTmTs & $55,23 \mathrm{i}$ & $30,33 \mathrm{~cd}$ & $37,67 \mathrm{de}$ & $45,00 \mathrm{e}$ \\
\hline BTmTk & $59,84 \mathrm{j}$ & $35,33 \mathrm{gh}$ & $46,33 \mathrm{i}$ & $56,00 \mathrm{i}$ \\
\hline $\mathrm{BTmTr}$ & $20,97 \mathrm{a}$ & $28,00 \mathrm{ab}$ & $34,67 \mathrm{~b}$ & $38,67 \mathrm{c}$ \\
\hline BTmSm & $39,33 \mathrm{~g}$ & $29,00 \mathrm{bcd}$ & $40,33 \mathrm{fg}$ & $49,67 \mathrm{f}$ \\
\hline BTmMj & $26,22 \mathrm{c}$ & $33,67 \mathrm{fg}$ & $44,00 \mathrm{~h}$ & $52,67 \mathrm{gh}$ \\
\hline $\mathrm{BTmSr}$ & $38,59 \mathrm{fg}$ & $36,67 \mathrm{~h}$ & $44,00 \mathrm{~h}$ & $56,33 \mathrm{ij}$ \\
\hline BTmRa & $49,69 \mathrm{~h}$ & $36,67 \mathrm{~h}$ & $48,00 \mathrm{i}$ & $58,00 \mathrm{j}$ \\
\hline MTmMs & $29,92 \mathrm{~d}$ & 32,33 ef & $42,00 \mathrm{gh}$ & $51,00 \mathrm{fg}$ \\
\hline $\mathrm{MTmJr}$ & $31,91 \mathrm{e}$ & $28,00 \mathrm{ab}$ & 39,00 ef & $45,00 \mathrm{e}^{0}$ \\
\hline MTmIn & $24,26 \mathrm{~b}$ & $27,67 \mathrm{ab}$ & $31,33 \mathrm{a}$ & $34,00 \mathrm{a}$ \\
\hline MAgIn & $38,33 \mathrm{fg}$ & $39,33 \mathrm{i}$ & $53,33 \mathrm{j}$ & $62,33 \mathrm{k}$ \\
\hline MAgPd & $24,73 \mathrm{bc}$ & $30,67 \mathrm{de}$ & 39,33 ef & 49,331 \\
\hline $\operatorname{BNT}_{(0,05)}$ & 1,17 & 1,69 & 2,07 & 1,83 \\
\hline
\end{tabular}

Angka dalam lajur yang diikuti oleh huruf yang sama menunjukkan tidak berbeda nyata berdasar uji $\mathrm{BNT}_{0,05}$.

penentu patogenisitas jamur. Jamur yang lebih patogenik cenderung memiliki kerapatan dan viabilitas konidia lebih tinggi. Isolat-isolat B. bassiana pada penelitian ini cenderung lebih patogenik dibandingkan M. anisopliae. Tinggi rendahnya kerapatan dan viabilitas konidia jamur selain ditentukan oleh faktor genetik juga dipengaruhi faktor luar, antara lain suhu, $\mathrm{pH}$, dan lamanya masa inkubasi. Suhu dan $\mathrm{pH}$ yang ideal untuk perbanyakan konidia $M$. anisopliae adalah $25-30^{\circ} \mathrm{C}$ dan $\mathrm{pH} 7$ (Soundarapandian \& Chandra, 2007). Toledo et al. (2010) menyatakan perkecambahan konidia $B$. bassiana and M. anisopliae mencapai masing-masing $95,50 \%$ dan $100 \%$ bila suspensi jamur diinkubasikan selama 72 jam.

\section{SIMPULAN}

Spesies jamur entomopatogen yang ditemukan dari tanah lebak dan pasang surut Sumatera Selatan adalah B. bassiana and M. anisopliae. Mortalitas larva
S. incertulas tertinggi $(98,33 \%)$ ditemukan pada isolat Bplus B. bassiana dan terendah ditemukan pada MTmIn $(57,50 \%)$ isolat $M$. anisopliae dan $\mathrm{BTm} \operatorname{Tr}(57,50 \%)$ isolat B. bassiana. Koloni jamur tumbuh lebih cepat mulai hari kedua hingga keempat setelah inkubasi tetapi pertumbuhan semakin lambat setelah hari kelima. Kerapatan konidia tertinggi terjadi pada isolat $B$. Bassiana BPcMs $\left(63,33 \times 10^{6}\right.$ konidia $\left.\mathrm{mL}^{-1}\right)$ yang tidak berbeda nyata dengan BPlus isolat $B$. bassiana $\left(63,11 \times 10^{6}\right.$ konidia $\left.\mathrm{mL}^{-1}\right)$ juga. Dengan demikian, isolat B. bassiana lebih efektif daripada $M$. anisopliae dalam membunuh larva $S$. incertulas.

\section{SANWACANA}

Penelitian ini merupakan bagian dari Insentif Riset Sistem Inovasi Nasional, Kementerian Riset dan Teknologi, Republik Indonesia Tahun Anggaran 2012 dengan kontrak nomor: 1.55/SEK/IRS/PPK///2012, tanggal 16 Januari 2012. 


\section{DAFTAR PUSTAKA}

Bidochka MJ, Kamp AM, \& Decroos JNA. 2000. Insect pathogenic fungi: from genes to populations. Fungal Pathol.42(2):171-193.

Bustillo AE, Bernal MG, Benavides P, \& Chaves B. 1999. Dynamics of Beauveria bassiana and Metarhizium anisopliae infecting Hypothenemus hampei (Coleoptera: Scolytidae) populations emerging from fallen coffee berries. The Florida Entomologist 82(4):491-498.

Hasyim A \& Azwana. 2003. Patogenisitas isolat Beauveria bassiana (Balsamo) Vuillemin dalam mengendalikan hama penggerek bonggol pisang, Cosmopolites sordidus Germar. Jurnal Hortikutura 13(2):120-130.

Herlinda S. 2010. Spore density and viability of entomopathogenic fungal isolates from Indonesia, and its virulence against Aphis gossypii Glover Homoptera: Aphididae). Tropical Life Sciences Research. 21(1):13-21.

Herlinda S, Hamadiyah, Adam T, \& Thalib R. $2006 a$. Toksisitas isolat-isolat Beauveria bassiana (Bals.) Vuill. terhadap nimfa Eurydema pulchrum (Westw.) (Hemiptera: Pentatomidae). Agria 2(1):34-37.

Herlinda S, Utama MD, Pujiastuti Y, \& Suwandi. 2006b. Kerapatan dan viabilitas spora Beauveria bassiana (Bals.) Vuill. akibat subkultur dan pengayaan media, serta virulensinya terhadap larva Plutella xylostella (Linn.). J. HPT Tropika 6(1):70-78.

Herlinda S, Irsan C, Mayasari R, \& Septariani S. 2010. Identification and selection of entomopathogenic fungi as biocontrol agents for Aphis gossypii from South Sumatra. Microbiology Indonesia 4(3):137-142.

Herlinda S, Mulyati SI, \& Suwandi. 2008a. Jamur entomopatogen untuk mengendalikan wereng coklat pada tanaman padi. Agritrop 27(3):119126.

Herlinda S, Mulyati SI, \& Suwandi. 2008b. Selection of isolates of entomopathogenic fungi, and the bioefficacy of their liquid production against Leptocorisa oratorius Fabricius nymphs. Microbiology Indonesia 2(3):141-145.
Herlinda S, Waluyo, Estuningsih SP, \& Irsan C. 2008c. Perbandingan keanekaragaman spesies dan kelimpahan arthropoda predator penghuni tanah di sawah lebak yang diaplikasi dan tanpa aplikasi insektisida. J. Entomol. Indon. 5(2): 96:107.

Herlinda S, Pujiastuti Y, Pelawi J, Riyanta A, Nurnawati E, \& Suwandi. 2005a. Patogenisitas isolat-isolat Beauveria bassiana (Bals.) Vuill. terhadap larva Plutella xylostella (L.) (Lepidoptera: Plutellidae) di rumah kaca. Inovasi 2(2):85-92.

Herlinda S, Sari EM, Pujiastuti Y, Suwandi, Nurnawati E, \& Riyanta A. 2005b. Variasi virulensi strainstrain Beauveria bassiana (Bals.) Vuill. terhadap larva Plutella xylostella (L.) (Lepidoptera: Plutellidae). Agritrop 24(2):52-57.

Khodijah, Herlinda S, Irsan C, Pujiastuti Y, \& Thalib R. 2012. Artropoda predator penghuni ekosistem persawahan lebak dan pasang surut Sumatera Selatan. Jurnal Lahan Suboptimal 1(1):57-63.

Lui HL \& Bauer LS. 2006. Susceptibility of Agrilus planipennis (Coleoptera: Buprestidae) to Beauveria bassiana and Metarhizium anisopliae. J. Econ. Entomol. 99(4):1096-1103.

Nunilahwati H, Herlinda S, Irsan C, \& Pujiastuti. 2012. Eksplorasi, isolasi, dan seleksi jamur entomopatogen Plutella xylostella (Lepidoptera:Yponomeutidae) pada tanaman caisin (Brassica chinensis) di Sumatera Selatan. J. HPT Tropika 12(1):1-11.

Prayogo Y, Tengkano W, \& Marwoto. 2005. Prospek cendawan entomopatogen Metarhizium anisopliae untuk mengendalikan ulat grayak Spodoptera litura pada kedelai. J. Litbang. Pertanian 24(1):19-26.

Soundarapandian P \& Chandra R. 2007. Mass production of endomopathogenic fungus Metarhizium anisopliae (Deuteromycota; Hyphomycetes) in the laboratory. Res. J. Microbiol. 2:690-705.

Toledo AV, Remes Lenicov AMM, \& López Lastra CC. 2010. Histopathology caused by the entomopathogenic fungi, Beauveria bassiana and Metarhizium anisopliae, in the adult planthopper, Peregrinus maidis, a maize virus vector. Journal of Insect Science 10:35 available online: insectsicence.org/10.35 
Usyati N, Buchori D, Manuwoto S, Hidayat P, \& Loedin HIS. 2009. Keefektifan padi transgenik terhadap hama penggerek batang padi kuning Scirpophaga incertulas (Walker) (Lepidoptera: Crambidae). J. Entomol.Indon. 6(1):30-41.
Wilyus, Nurdiansyah F, Herlinda S, Irsan C, \& Pujiastuti Y. 2012. Potensi parasitoid telur penggerek batang padi kuning Scirpophaga incertulas Walker pada berbagai tipologi lahan di Provinsi Jambi. J. HPT Tropika12(1):56-63. 